\title{
A comparative phenotypical analysis of rheumatoid nodules and rheumatoid synovium with special reference to adhesion molecules and activation markers
}

Dirk Elewaut, Filip De Keyser, Nathalie De Wever, Dominique Baeten, Nancy Van Damme, Gust Verbruggen, Claude Cuvelier, Eric M Veys

\begin{abstract}
Objectives-(1)To analyse the in situ expression of adhesion molecules in rheumatoid nodules. (2) To compare the endothelial expression of adhesion molecules in synovial tissue and subcutaneous nodules obtained from the same patients. (3) To compare the expression of adhesion molecules and activation markers on $T$ cell lines from nodules and synovium.

Methods-(1) Immunohistochemical analysis by APAAP technique of $E$ selectin, CD44, ICAM-1, PECAM-1, and VCAM-1 was performed on 10 rheumatoid nodules from seven patients with rheumatoid arthritis (RA); nodules and synovium were simultaneously analysed from three patients. (2) $T$ cell lines were generated from RA nodules $(n=7)$ and synovium $(n=7)$ by interleukin 2 expansion, and subsequently characterised by flow cytometry for surface expression of $\alpha E \beta 7, \alpha 4 \beta 7$, CD44, L selectin, LFA-1a, PECAM-1, and CD30.

Results-(1) In rheumatoid nodules, the palisading layer strongly stains for ICAM-1 and PECAM-1, but less pronounced for CD44. VCAM-1 staining was usually negative. ICAM-1 is upregulated in the vessels surrounding the central zone of fibrinoid necrosis. The immunohistological picture in different nodules derived from the same patient was similar. (2) The endothelial expression of adhesion molecules is comparable in RA nodules and synovium on an individual level, except for $E$ selectin, which is overexpressed in nodule endothelium. (3) $T$ cell lines from nodules and synovium display similar adhesion molecule profiles. However, the expression of CD30, a $\mathrm{T}$ cell activation marker linked with Th2 subsets, is higher in nodules compared with synovium.

Conclusion-These data support a recirculation hypothesis of $T$ cells between articular and extra-articular manifestations in RA, although the activation state of the $T$ cells in each of these localisations may differ.

(Ann Rheum Dis 1998;57:480-486)
\end{abstract}

Rheumatoid arthritis (RA) is a chronic autoimmune disease characterised by chronic polyarthritis leading to joint destruction. Although the exact pathogenesis of this disease is unknown, a number of observations suggest that CD4+ T lymphocytes play a central part in the induction or perpetuation of the chronic inflammation. These include: the strong linkage of RA with certain class II genes, the infiltration of $\mathrm{T}$ cells (predominantly CD4+ $\mathrm{T}$ cells) at the primary sites of inflammation, the ability of $\mathrm{T}$ cells to transfer the disease in experimental animal models of arthritis, and the clinical benefit of some $\mathrm{T}$ cell directed treatments. ${ }^{1-5}$ Conversely, it has been postulated that synovitis is maintained by autocrine and paracrine pathways involving macrophages and fibroblasts. ${ }^{67}$ In an attempt to reconcile both apparently diverse theories on the pathogenesis of RA, a new model has been proposed in which $T$ cells and macrophages/fibroblasts both play a major pathogenic part, albeit, in different phases of the disease. $^{8}$

Besides the presence of joint inflammation, a number of extra-articular manifestations may also occur in RA such as the formation of rheumatoid nodules, pleuritis, episcleritis, and vasculitic skin lesions. The presence of subcutaneous nodules in para-articular subcutaneous tissue in RA patients is commonly regarded as an extra-articular manifestation in RA, occurring in 20 to $30 \%$ of white patients. ${ }^{9}$ Such nodules typically develop subcutaneously over the extensor site of small and larger joints, but they may also develop in tendons or in visceral organs such as the lungs. Rheumatoid factor is almost always found in high titres in the serum of patients with rheumatoid nodules. ${ }^{10}$ Histologically, rheumatoid nodules have a granuloma-like structure composed of three zones: an inner zone of central necrosis, a surrounding cellular palisading zone, and an outer area of lymphoid aggregates organised around small vessels. ${ }^{10}{ }^{11}$ The major proportion of the palisaded cells are macrophages. $T$ cells are found in variable numbers distributed among the macrophages, and more pronounced, in the lymphoid aggregates concentrated around small vessels.

The immune infiltrate in rheumatoid nodules is characterised by a number of interesting features. A significantly oligoclonal outgrowth of $\mathrm{T}$ lymphocytes from rheumatoid nodules after interleukin 2 (IL2) expansion has previously been reported by our group, reflecting a clonally restricted $\mathrm{T}$ cell activation in situ. ${ }^{12}$ The dominant $\mathrm{T}$ cell receptors (TCRs), assessed by using monoclonal antibodies
Accepted for publication 11 June 1998 
Table 1 Clinical and laboratory parameters of patients with rheumatoid arthritis from whom subcutaneous nodules and synovial tissue were obtained for immunohistochemistry

\begin{tabular}{|c|c|c|c|c|c|c|c|}
\hline Patient & $D \mathcal{F E}$ & $D V A$ & $D K L$ & $T W$ & $\mathrm{DCH}$ & $D P H$ & $D V A$ \\
\hline Sex & $\mathrm{F}$ & $M$ & $M$ & $\mathrm{M}$ & $\mathrm{M}$ & $\mathrm{M}$ & $\mathrm{F}$ \\
\hline Age & 49 & 71 & 69 & 44 & 68 & 71 & 56 \\
\hline Disease duration (y) & 18 & 43 & 20 & 1 & 8 & 22 & 37 \\
\hline Swollen joint count & 0 & 0 & 0 & 6 & 8 & 6 & 0 \\
\hline Bone erosions & + & + & + & + & + & + & + \\
\hline Existence of resected nodules & $>1$ year & $>1$ year & 8 months & $>1$ year & 2 weeks & $>1$ year & $>1$ year \\
\hline $\mathrm{RF}$ & + & + & + & + & + & + & + \\
\hline APF & + & + & + & + & + & + & + \\
\hline $\operatorname{ESR}(\mathrm{mm} / 1 \mathrm{st} \mathrm{h})$ & 4 & 13 & 16 & 13 & 54 & 34 & 86 \\
\hline $\mathrm{CRP}(\mathrm{mg} \%)$ & 0.7 & 0.8 & 2.0 & 1.0 & 10.7 & 1.6 & 2.4 \\
\hline DMARD & MTX & MTX & MTX & MTX & - & LEVA & SASP \\
\hline DRB1 typing & $\mathrm{ND}$ & $\begin{array}{l}0401 \\
0101\end{array}$ & $\mathrm{ND}$ & ND & ND & ND & ND \\
\hline Resected tissue samples & $\mathrm{RN}$ & $\mathrm{RN}$ & $\mathrm{RN}$ & $\mathrm{RN}$ & $\begin{array}{l}\text { RN } \\
\text { SYN }\end{array}$ & $\begin{array}{l}\text { RN } \\
\text { SYN }\end{array}$ & $\begin{array}{l}\text { RN } \\
\text { SYN }\end{array}$ \\
\hline
\end{tabular}

RF: rheumatoid factor; APF: antiperinuclear factor; CRP: C reactive protein; ESR: erythrocyte sedimentation rate; DMARD: disease modifying antirheumatic drugs; LEVA: levamisole; MTX: methotrexate; ND: not done; RN: rheumatoid nodule; SASP: sulphasalasin; SYN: synovial tissue.

specific for human TCR variable region gene products, can differ from patient to patient. However, a preferential outgrowth of $\mathrm{T}$ cell lines, which express only a distinct TCR family, was observed in different nodules derived from the same patients, even at different time intervals (unpublished observations). ${ }^{12}$ Furthermore, clonally restricted $\mathrm{T}$ cell lines from rheumatoid nodules have been shown to contain highly related CDR3 sequences, strongly suggesting an antigen driven $\mathrm{T}$ cell activation in situ. ${ }^{13}$

The pathogenic mechanism leading to the formation of rheumatoid nodules remains unclear, and the exact immunological relation between joint inflammation and subcutaneous nodules is as yet undefined. A key question is whether the same $\mathrm{T}$ cells that mediate the formation of these nodules are also involved in the pathogenesis of arthritis. In favour of this hypothesis is the observation that the same TCR family was found to be overexpressed on certain $\mathrm{T}$ cell lines from rheumatoid nodules and rheumatoid synovium, but not of control tissue (unpublished observations). Moreover, $\mathrm{T}$ cell lines from rheumatoid nodules showed a preferential in vitro adherence to rheumatoid synovium and rheumatoid nodules, while no binding was observed on control tissues such as skin or tonsil (unpublished observations).

To further explore the origin of the immune infiltrate in subcutaneous nodules and its relation to the synovial inflammation, a comparative study on the expression of an array of adhesion molecules was conducted in both disease manifestations. Adhesion molecules play a critical part in the process of lymphocyte trafficking, and thus in the influx of effector cells into sites of inflammation. ${ }^{14}$ Such molecules constitute the basis for cell-cell as well as cell-matrix interactions. However, these receptors not only regulate cell migration but may also regulate important functional activities of the cell. In this paper, we report on the in situ expression of $\mathrm{E}$ selectin, CD44, ICAM-1, PECAM-1, and VCAM-1 in rheumatoid nodules. In addition, the endothelial expression of E selectin, ICAM-1, PECAM-1, and VCAM-1 was compared in both rheumatoid nodules and synovium derived from the same patients. Finally, cell surface expression of $\alpha \mathrm{E} \beta 7, \alpha 4 \beta 7$, CD44, LFA-1 $\alpha$, L selectin, PECAM-1, and CD30 on $\mathrm{T}$ cell lines from RA nodules and synovium was analysed by flow cytometry.

\section{Methods}

PATIENTS

Nineteen patients with classic RA, according to the ACR criteria $^{15}$ were entered in the study after giving informed consent. Sixteen rheumatoid nodules were obtained from 13 patients with classic RA. These nodules were removed upon the patient's request after mechanical irritation or for aesthetical reasons. Rheumatoid synovium was obtained from $10 \mathrm{RA}$ patients during joint replacement for destructive arthrits or by needle arthroscopy of the knee during diagnostic intervention. All but one patient from whom synovial tissue was

Table 2 Clinical and laboratory parameters of patients with rheumatoid arthritis from whom synovial tissue was obtained for $T$ cell expansion

\begin{tabular}{|c|c|c|c|c|c|c|c|c|c|c|c|c|}
\hline Patient & $P \mathcal{F}$ & $C \mathcal{F}$ & $G M$ & $M R$ & $D C f$ & $S C M$ & $V L$ & $H C$ & $R P$ & $S M$ & $D M$ & DPS \\
\hline$\overline{\text { Sex }}$ & $\mathrm{F}$ & $\mathrm{F}$ & $\mathrm{F}$ & $M$ & $\mathrm{~F}$ & $\mathrm{~F}$ & $M$ & $\mathrm{~F}$ & $\mathrm{~F}$ & $\mathrm{~F}$ & $\mathrm{~F}$ & $\mathrm{~F}$ \\
\hline Age & 49 & 64 & 60 & 65 & 54 & 51 & 46 & 34 & 72 & 67 & 53 & 63 \\
\hline Disease duration $(\mathrm{y})$ & 5 & 17 & 29 & 25 & 9 & 20 & 0.4 & 0.4 & 0.4 & 0.3 & 6 & 0.6 \\
\hline Swollen joint count & 3 & 0 & 2 & 0 & 0 & 6 & 6 & 8 & 19 & 6 & 9 & 6 \\
\hline Bone erosions & + & + & + & + & + & + & + & - & + & + & + & - \\
\hline Existence of resected nodules & 6 months & $>1$ year & $>1$ year & $>1$ year & $>1$ year & $>1$ year & - & - & - & - & - & - \\
\hline RF & + & + & + & + & + & + & - & + & + & - & + & - \\
\hline $\mathrm{APF}$ & ND & + & + & ND & ND & + & + & + & + & - & + & - \\
\hline $\operatorname{ESR}(\mathrm{mm} / 1 \mathrm{st} \mathrm{h})$ & 43 & 19 & 14 & 56 & 12 & 18 & 11 & 30 & 80 & 66 & 22 & 24 \\
\hline CRP (mg\%) & 0.2 & 0.6 & 0.19 & 7.2 & 0.2 & 5.5 & 0.8 & 2.7 & 7.7 & 4.0 & 4.0 & 43 \\
\hline DMARD & - & MTX & MTX & MTX & - & MTX & no & no & no & no & MTX & no \\
\hline DRB1 typing & $\begin{array}{l}1001 \\
1102\end{array}$ & ND & $\begin{array}{l}0101 \\
1301\end{array}$ & ND & ND & $\begin{array}{l}0401 \\
0408\end{array}$ & ND & $\begin{array}{l}0401 \\
0301\end{array}$ & ND & $\begin{array}{l}0404 \\
0408\end{array}$ & ND & 0101 \\
\hline Resected tissue samples & $\mathrm{RN}$ & $\mathrm{RN}$ & $\mathrm{RN}$ & $\mathrm{RN}$ & $\mathrm{RN}$ & $\begin{array}{l}\text { RN } \\
\text { SYN }\end{array}$ & SYN & SYN & SYN & SYN & SYN & SYN \\
\hline
\end{tabular}




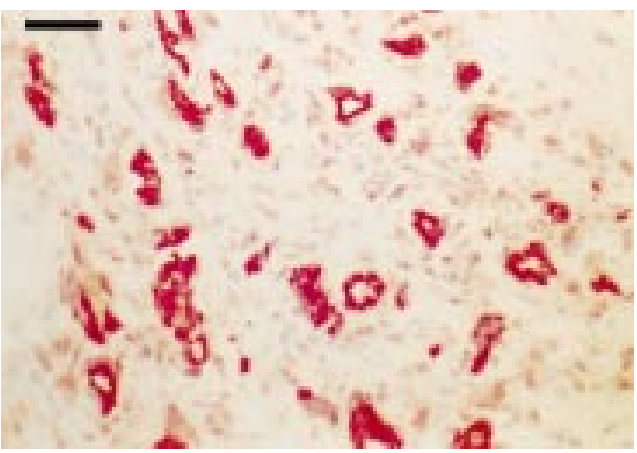

Figure 1 Immunostaining of an early onset rheumatoid nodule (removal two weeks after appearance) for PECAM-1. Note impressive vascularisation in the absence of fibrinoid necrosis. Bar $=100 \mu \mathrm{m}$.

collected had active peripheral synovitis. The clinical and serological data of the RA patients, from whom rheumatoid nodules and synovium were obtained, are summarised in tables 1 and 2. Clinical characteristics of patients from whom samples were collected for immunohistochemistry are shown in table 1, and those from whom tissue samples were used for $\mathrm{T}$ cell expansion are shown in table 2 . The rheuma-
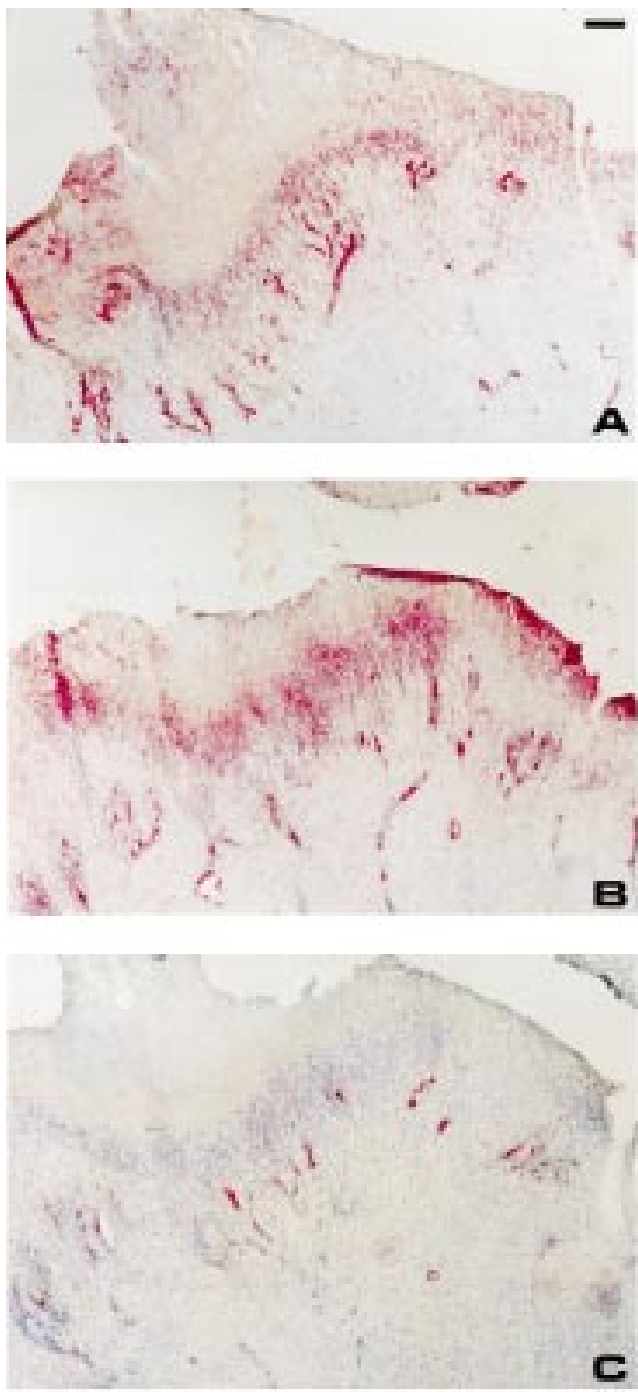

Figure 2 Rheumatoid nodules stained for PECAM-1 (A), ICAM-1 (B), E-selectin (C), VCAM-1 (D,E), and CD44 (F). Single staining using APAAP technique counterstained with haematoxylin. $A-D:$ bar $=200 \mu \mathrm{m} ; E-F:$ bar $=100 \mu \mathrm{m}$.

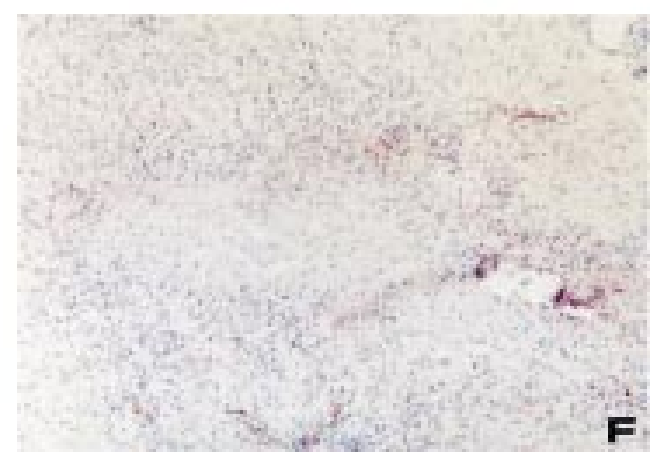

Table 3 Expression of adhesion molecules in rheumatoid nodules on endothelium and in the palisading layer of histiocytes

\begin{tabular}{llll}
\hline & $\begin{array}{l}\text { Endothelium } \\
\text { Around } \\
\text { necrosis }\end{array}$ & $\begin{array}{l}\text { Endothelium } \\
\text { On distance } \\
\text { from necrosis }\end{array}$ & Histiocytes \\
\hline ICAM-1 & $3(2-3)$ & $2(1-3)$ & $2(0-3)$ \\
E selectin & $2(1-3)$ & $2(1-3)$ & $0(0-0)$ \\
CD44 & $0(0-0)$ & $0(0-0)$ & $1(0-2)$ \\
VCAM-1 & $1(0-2)$ & $1(0-1)$ & $0(0-1)$ \\
PECAM-1 & $3(1-3)$ & $3(1-3)$ & $2(1-3)$ \\
\hline
\end{tabular}

The data represent medians (range) of the semiquantitative scores (0-3), see Methods.

toid nodule obtained from patient DKL was not only used for immunohistochemistry but also for $\mathrm{T}$ cell expansion. The clinical data of this patient are only shown in table 1 .

This study was approved by the Ethical Committee of the local Faculty of Medicine.

\section{T LYMPHOCYTE EXPANSION}

$\mathrm{T}$ cell lines were generated as reported previously. ${ }^{12}$ Briefly, small tissue fragments from rheumatoid nodules and rheumatoid synovium ( 2 to $5 \mathrm{~mm}^{3}$ ) were transferred into separate wells on a 24 well culture plate (Gibco,
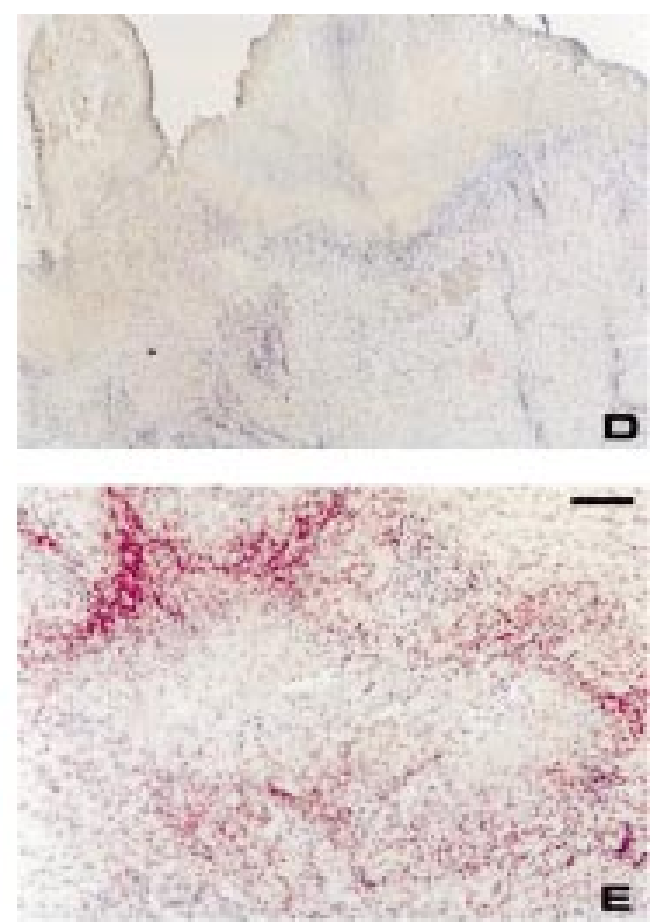
Grand Island, NY) and incubated in RPMI medium (Gibco) containing recombinant IL2 (50 U/ml; Eurogenetic, Belgium), 10\% autologous serum, antibiotics ( $10 \mathrm{U} / \mathrm{ml}$ Penicillin-G, $10 \mathrm{U} / \mathrm{ml}$ streptomycin sulphate and $0.025 \mu \mathrm{g}$ amphotericin B) and $0.5 \%$ L-glutamine.

A total of 21 lymphocyte cultures of rheumatoid nodules and 17 from rheumatoid synovium were obtained for flow cytometric analysis.

\section{FLOW CYTOMETRIC ANALYSIS}

Phenotypical analysis of the lymphocytes was performed using monoclonal antibodies (Mab) conjugated with either fluorescein isothiocyanate (FITC), phycoerythrin (PE) or peridinin chlorophyll protein (PerCP). Cellular distribution was studied using anti-CD3 (Leu4, clone SK7), -CD4 (Leu3a, clone SK3), and -CD8 (Leu2a, clone SK1) (Becton Dickinson (BD), San Jose, CA, USA). To determine expression of a number of adhesion molecules a panel of Mab directed against the following was used: L-selectin (clone SK11, BD), LFA-1a (CD11a, clone B-B15), PECAM-1(CD31, clone HC 1/6), CD44 (HCAM-1, clone F10442) (Serotec, Oxford, UK), and $\alpha \mathrm{E} \beta 7$ (CD103, HML-1, clone 2G5, Immunotech). Studies of $\alpha 4 \beta 7$ expression were performed by indirect staining with the Act-I Mab (a generous gift from Dr A Lazarovits), as previously described. ${ }^{16}{ }^{17}$ FITC conjugated goat antimouse IgG Mab (BD) was used as secondary antibody.

Isotype matched immunoglobulins that did not react with human leucocytes were used as controls (BD). Cells were resuspended in $1-5 \times$
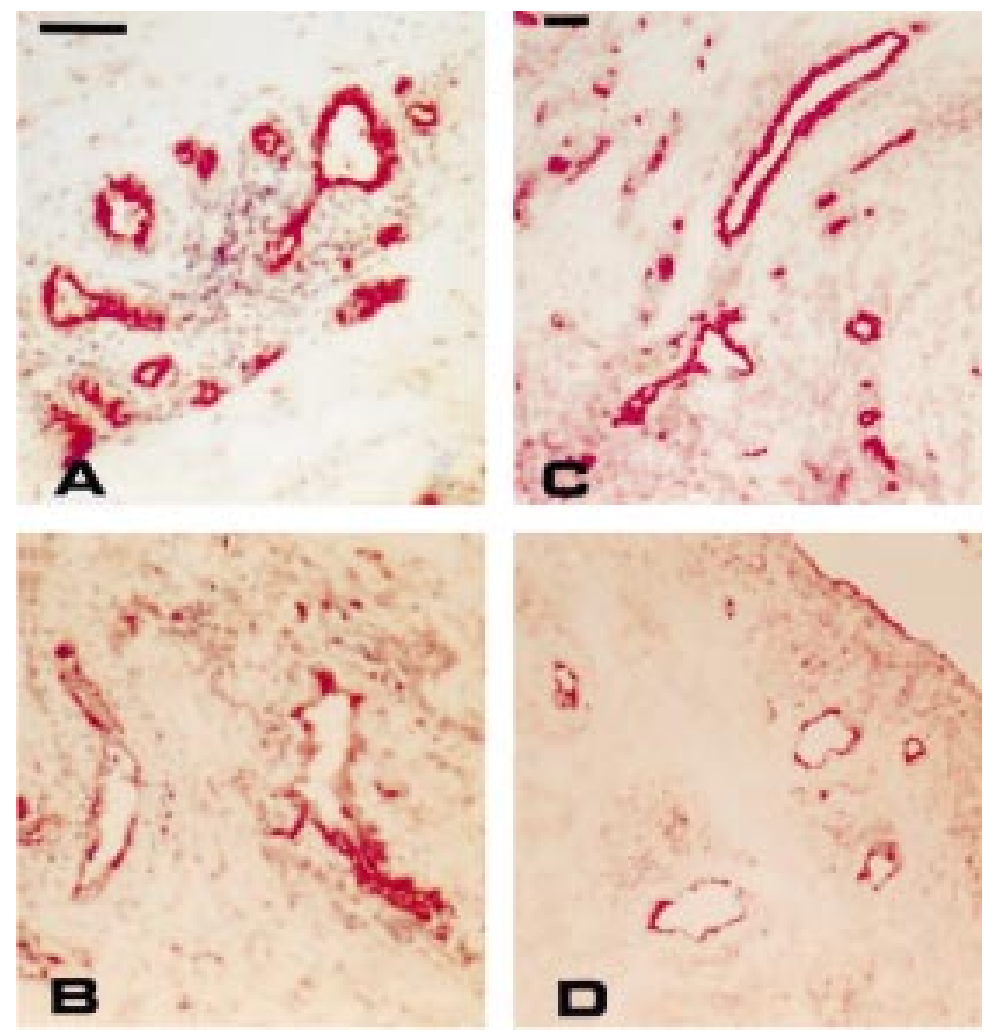

Figure 3 Endothelial expression of PECAM-1 $(A, C)$ and ICAM-1 $(B, D)$ in a rheumatoid nodule $(A, B)$ and rheumatoid synovium $(C, D)$. Single staining using APAAP technique counterstained with haematoxylin. Bar $=100 \mu \mathrm{m}$.
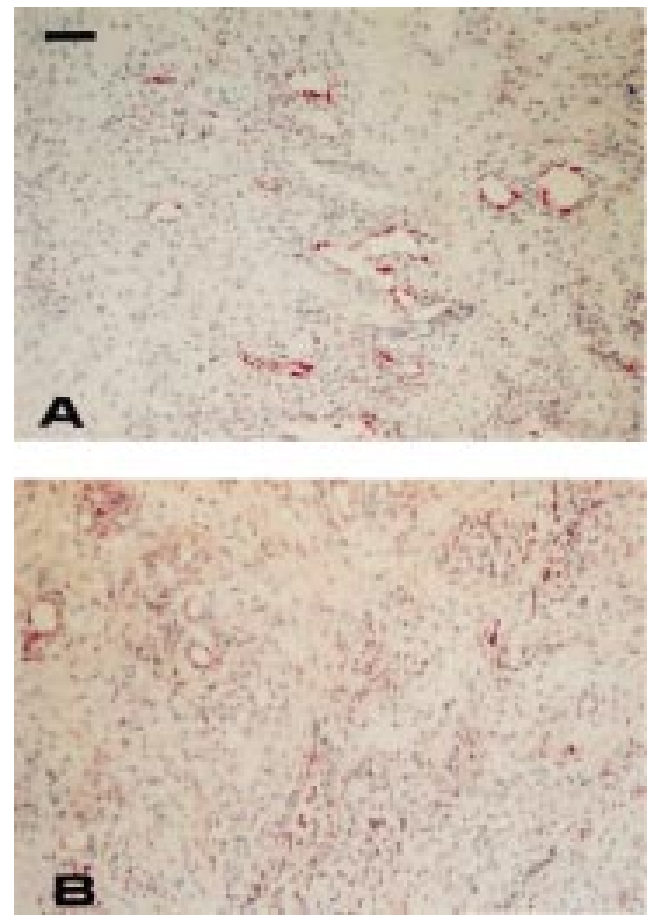

Figure 4 Endothelial expression of E-selectin $(A)$ and $V C A M-1$ (B) in a rheumatoid nodule. Single staining using APAAP technique counterstained with haematoxylin. Bar $=100 \mu \mathrm{m}$.

$10^{6} / \mathrm{ml}$ according to yield. For fluorochrome conjugated Mab stainings, aliquots $(100 \mu \mathrm{l})$ were incubated with the appropriate amount of Mab $(10 \mu \mathrm{l})$ in the dark at $4^{\circ} \mathrm{C}$ for 30 minutes. Cells were washed with $2 \mathrm{ml}$ of phosphate buffered saline (PBS). The cell suspension was mixed gently and centrifuged at $1600 \mathrm{rpm}$ for 10 minutes. Cells were fixed with $500 \mu$ PBS containing $1 \%$ paraformaldehyde and stored in the dark at $4^{\circ} \mathrm{C}$ until analysed.

The surface expression of antigens on the obtained cell lines was determined by quantitative three colour analysis with a FACSort (BD).

Isotype matched controls were used to establish the non-specific staining of the samples and to set the fluorescent markers on the FACSort. Routinely, 10000 events from each sample were collected. Data were analysed using LYSIS II and Attractors software (BD).

STATISTICAL ANALYSIS OF FLOW CYTOMETRIC DATA

Values are expressed as \% positive cells with median value and range. The Wilcoxon rank sum test was used to compare groups. A value of $p<0.05$ was considered as statistically significant.

IMMUNOHISTOCHEMISTRY

Parallel sections, $5 \mu \mathrm{m}$ thick, from rheumatoid nodules and rheumatoid synovium were analysed immunohistochemically using the alkaline phosphatase anti-alkaline phosphatase (APAAP) technique, as previously described. ${ }^{12}$ Cryostat sections were fixed in acetone for 10 minutes. Each section was incubated for 30 minutes with optimal concentrations of one of 
Table 4 Expression of adhesion molecules on endothelium and in the palisading layer of histiocytes in four different rheumatoid nodules simultaneously derived from the same patient $(T W)$

\begin{tabular}{|c|c|c|c|c|c|c|c|c|}
\hline & \multicolumn{4}{|c|}{ Endothelial expression } & \multicolumn{4}{|c|}{ Palisading layer of histiocytes } \\
\hline & $T W 1$ & $T W 2$ & $T W 3$ & $T W 4$ & $T W 1$ & $T W 2$ & $T W 3$ & $T W 4$ \\
\hline ICAM-1 & $2 \star-3$ & 3 & $2^{\star}-3$ & $2^{\star}-3$ & 1 & 2 & 1 & 1 \\
\hline E selectin & 2 & 1 & 2 & 2 & 0 & 0 & 0 & 0 \\
\hline CD44 & 0 & 0 & 0 & 0 & 1 & 1 & 2 & 2 \\
\hline VCAM-1 & 1 & 0 & 0 & 1 & 0 & 0 & 0 & 0 \\
\hline PECAM-1 & 3 & 3 & 3 & 3 & 1 & 2 & 2 & 2 \\
\hline
\end{tabular}

The data represent semiquantitative scores $\left(0-3\right.$, see Methods). ${ }^{\star}$ On distance from central zone of fibrinoid necrosis.

\section{Results}

IN SITU EXPRESSION OF ADHESION MOLECULES IN RHEUMATOID NODULES

Ten rheumatoid nodules from seven different RA patients were analysed immunohistochemically to determine in situ expression of E selectin, CD44, ICAM-1, PECAM-1, and VCAM-1. The majority of these nodules obtained had been present for six months or more: in these established nodules the classically described three layer structure was noted. In one patient $(\mathrm{DCH})$, however, the nodule had only appeared two weeks before removal. This recent onset nodule showed impressive neovascularisation (fig 1), in the absence of fibrinoid necrosis.

The palisading layer of histiocytes strongly stained for ICAM-1 and PECAM-1, and less pronounced CD44, as shown in figure 2 . VCAM-1 staining was usually negative, except in one patient (fig $2 \mathrm{E}$ ).

Table 3 shows the in situ expression of the various tested adhesion molecules. The expression of ICAM-1, VCAM-1, and E selectin, on endothelium from rheumatoid nodules displayed focal and segmental variation (fig 3 and 4). In contrast, the endothelial expression of PECAM-1 was constitutive. No endothelial staining with anti-CD44 was observed.

The endothelial expression of ICAM-1 was most abundant in areas that directly surround the central zone of fibrinoid necrosis. Moreover, E selectin staining on endothelium correlated with the duration of the nodules with an upregulation being observed in early onset nodules. Endothelial staining for VCAM-1 was generally weak.

In one patient, four different nodules were simultaneously obtained. Interestingly, similar immunohistochemical pictures were obtained from these different nodules, as shown in table 4.

No obvious differences could be documented between nodules induced by either treatment with methotrexate or from those in patients with other disease modifying antirheumatic drugs (DMARD).

IN SITU EXPRESSION OF ADHESION MOLECULES ON ENDOTHELIUM IN RHEUMATOID NODULES AND SYNOVIAL TISSUE DERIVED FROM THE SAME PATIENTS

In addition to the immunohistological study of adhesion molecule expression in rheumatoid nodules, another objective in this investigation, solved by mutual agreement.

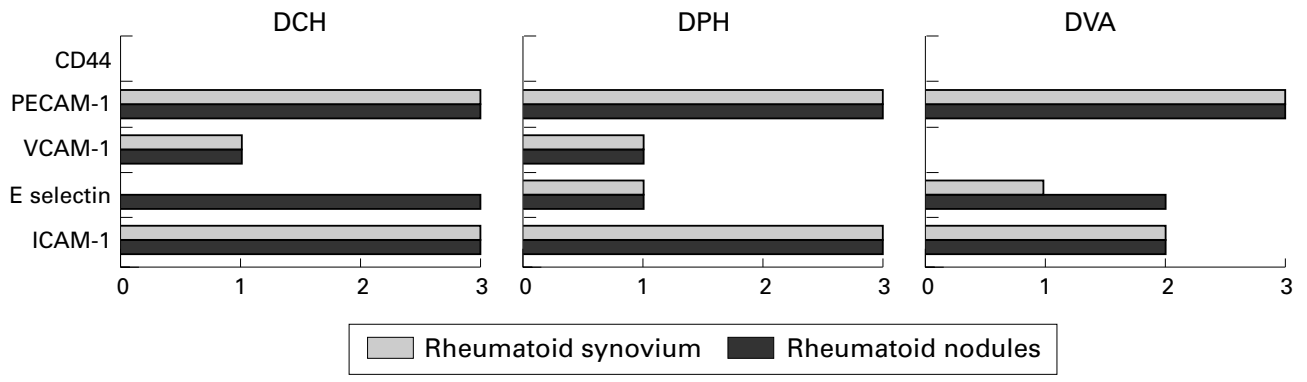

Figure 5 Endothelial expression of adhesion molecules in simultaneously obtained rheumatoid nodules and rheumatoid synovium of three patients with rheumatoid arthritis. Data represent semiquantitative scores on endothelium. 
Table 5 Flowcyotmetric expression of adhesion molecules and CD30 on CD4+ $T$ cell lines from rheumatoid nodules ( $n=21)$ and rheumatoid synovium $(n=17)$. Data are expressed as $\%$ positive cells (median and range) on $T$ cell lines

\begin{tabular}{|c|c|c|c|c|c|c|c|}
\hline & $a E \beta 7$ & $a 4 \beta 7$ & $L F A-1 a$ & $C D 44$ & $L$ selectin & PECAM-1 & CD30 \\
\hline Nodules & $2.5(0.3-15.8)$ & $25.9(0.7-69.7)$ & $99.9(99.5-100)$ & $99.8(96.6-100)$ & $56.6(6.8-94.8)$ & $1.2(0.2-4.7)$ & $18.1(1.0-79.1)^{\star}$ \\
\hline Synovium & $4.8(0.6-8.8)$ & $18.0(9.1-81.0)$ & $100(99.7-100)$ & $99.9(99.6-100)$ & $47.4(7.6-94.6)$ & $1.9(0.3-4.7)$ & $10.4(0.9-46.8)^{\star}$ \\
\hline
\end{tabular}

was to compare the endothelial expression of adhesion molecules in both rheumatoid nodules and synovial tissue within the same patients. In three of seven RA patients from whom rheumatoid nodules were obtained for immunohistological analysis, synovial tissue could also be obtained during joint replacement surgery. As shown in figures 3, 4, and 5, the endothelial expression of ICAM-1, VCAM-1, and PECAM-1 was very similar within the same patient. In contrast, E selectin expression was higher in rheumatoid nodules versus synovial tissue.

EXPRESSION OF ADHESION MOLECULES ON T CELL LINES FROM RHEUMATOID NODULES AND

RHEUMATOID SYNOVIUM

In total, $38 \mathrm{~T}$ cell lines were generated from the rheumatoid nodules $(n=21)$ and rheumatoid synovium $(n=17)$ of patients included in this study. These $\mathrm{T}$ cell lines were almost exclusively CD4 positive in both rheumatoid nodules (fraction $\mathrm{CD} 3+\mathrm{CD} 4+/ \mathrm{CD} 3+$ : median: 99.5\% ; range: $98.4-100$ ) and rheumatoid synovium (fraction CD3+CD4+/CD3+: median: $97.8 \%$; range: $65.1-100)$. Table 5 shows the expression of the various adhesion molecules and activation markers on $\mathrm{CD} 4+\mathrm{T}$ cell subsets. As the CD8+ T cells were virtually absent in rheumatoid nodules and rheumatoid synovium, only the expression on CD $4+\mathrm{T}$ cells is demonstrated.

The expression of $\alpha \mathrm{E} \beta 7, \alpha 4 \beta 7, \mathrm{CD} 44, \mathrm{~L}$ selectin, LFA-1 $\alpha$, and PECAM-1, was found to be similar in rheumatoid nodules and synovium. However, the expression of CD30, a T cell activation marker linked with $\mathrm{T}$ helper 2 subsets, was found to be overexpressed in rheumatoid nodules, compared with rheumatoid synovium $(\mathrm{p}<0.05$; table 5$)$.

\section{Discussion}

This study focuses on the expression of adhesion molecules and activation markers in rheumatoid nodules and rheumatoid synovium, to further characterise the immune infiltrate in rheumatoid nodules and its relation to the synovial inflammation.

The expression of adhesion molecules on $\mathrm{T}$ cell lines generated from rheumatoid nodules and rheumatoid synovium, as determined by flow cytometry, was found to be similar in both sites, as was the CD4/CD8 distribution. Noteworthy is the finding that analogous experiments in other diseases (synovium from patients with spondyloarthropathy) or other tissues (ileum or colon) generated distinct results (unpublished observations).

The endothelial ligands of a number of these molecules were studied in both rheumatoid nodules and synovium of the same patients. The expression of PECAM-1, ICAM-1, and
VCAM-1 was found to be similar in both locations, although the levels of expression could differ from patient to patient. Conversely, E selectin expression was found to be higher in rheumatoid nodules, compared with rheumatoid synovium. This could be consistent with a role for E selectin in preferential recruitment of inflammatory cells to rheumatoid nodules. In support of this hypothesis is the finding that the highest levels of $\mathrm{E}$ selectin expression were found in early onset rheumatoid nodules. However, it should be borne in mind that only a limited number of adequate synovial tissue samples could be obtained from patients from whom the nodules were also removed, as the opportunities to collect such samples are rare.

Of similar interest was the finding that the immunohistological picture and the levels of expression of adhesion molecules was similar in different nodules derived from the same person.

Within rheumatoid nodules, the expression of ICAM-1, E selectin, and VCAM-1 showed segmental and focal variation, which is a hallmark of inducible cell adhesion molecules. This was not however, the case for PECAM-1, which stains endothelial cells constitutively. An interesting finding was the higher endothelial expression of ICAM-1 that was found in close proximity to the central zone of fibrinoid necrosis. This is also the area where the palisading layer of histiocytes is situated. The upregulation of ICAM-1 in this zone may therefore be induced by cytokines released by macrophages in this region, such as IL1, shown to be abundant in rheumatoid nodules. ${ }^{10} 18 \mathrm{It}$ seems that other cytokines may be also involved, as the expression of two other IL1 inducible adhesion molecules ${ }^{19-21}$ did not show such an upregulation. The endothelial expression of VCAM-1 was generally found to be weak and no regional variation of $E$ selectin expression was detected.

In contrast with the $\mathrm{T}$ cells and the endothelium from rheumatoid nodules, more data are available on the cells located in the palisading layer. Such cells seem to share some features with synovial intimal cells in that they consist of a dual population of macrophages. ${ }^{102-24}$ and fibroblastic cells. ${ }^{24}$ The fibroblastic cells from rheumatoid nodules differ from the synovial fibroblasts however, in their low expression of VCAM-1, the lack of uridine diphosphoglucose dehydrogenase, and $\beta 1$ integrin chain expression. ${ }^{24}$ The exception to this rule was noted in nodules containing central clefts, which were lined with cells showing features of synovial intimal cells. This study confirms the low to absent expression of VCAM-1 on the palisading layer. In contrast, the expression of CD44, ICAM-1, and PECAM-1 was more pronounced. 
Finally, the expression of CD30 on $\mathrm{T}$ cell lines generated from rheumatoid nodules was found to be higher than on those from rheumatoid synovium. This is of particular interest as CD30 has been linked with $\mathrm{T}$ helper 2 subsets. ${ }^{25} \mathrm{CD} 30$ is a $\mathrm{T}$ cell activation marker that is preferentially expressed on CD4+ subsets, and is more abundant on CD25 positive than CD25 negative $\mathrm{T}$ cell subsets. ${ }^{26}$ The distinctive expression of CD30 on nodule derived $\mathrm{T}$ cells compared with those from the synovium suggests a different functional state of $\mathrm{T}$ cells in both manifestations. Although no $\mathrm{T}$ cell cytokine profiles in rheumatoid nodules have yet been reported, a number of clinical findings suggest a discrepancy between the presence of extensive extra-articular manifestations and the inflammatory state of the joints. ${ }^{27}$ In contrast, an explosion of extra-articular activity is often accompanied by a reduction in articular inflammation. This has particularly been reported in patients treated with methotrexate. ${ }^{28}$

In conclusion, the phenotypical analysis of rheumatoid nodules and rheumatoid synovium showed similar expression of adhesion molecules at both the T lymphocyte and endothelial site, with the exception of $\mathrm{E}$ selectin. Expression of this molecule was found to be higher in rheumatoid nodules compared with synovial tissue, suggesting a role in the preferential recruitment of inflammatory cells to rheumatoid nodules. The observed similarities in adhesion molecule expression on $\mathrm{T}$ cells from rheumatoid nodules and synovium support a recirculation hypothesis of $\mathrm{T}$ cells between both localisations. Additional data supporting this hypothesis are: the overexpression of the same TCR family on certain T cell lines from rheumatoid nodules and rheumatoid synovium, but not of control tissue (unpublished observations) and the preferential in vitro adherence of nodular $\mathrm{T}$ cells to rheumatoid synovium and rheumatoid nodules, compared with control tissues (unpublished observations). The activation state of $\mathrm{T}$ cells in each of these localisations however, may differ, as $\mathrm{T}$ cell lines in rheumatoid nodules showed a higher expression of CD30.

We are indebted to Miss J Vermeersch for excellent technical assistance and to Dr D O'Neil for critical reading of the manuscript. This work was supported by NFWO grant 3.0028 .95 . Dirk Elewaut and Dominique Baeten are NFWO research assistants.

1 Stastny P. Association of the B-cell alloantigen DRw4 with rheumatoid arthritis. N Engl J Med 1978;298:869-71.

2 Van Boxel JJ, Paget SA. Predominantly T cell infiltrate in rheumatoid synovial membranes. N Engl J Med 1975;293: 517-21.

3 Duke O, Panayi GS, Janossy G, Poultier LW. An immunohistological analysis of lymphocyte subpopulations and their microenvironment in the synovial membranes of antibodies. Clin Exp Immunol 1982;49:22-30.
4 van Eden W, Holoshitz J, Nevo Z, Frenkel A, Klajman A, Cohen IR. Arthritis induced by a T-lymphocyte clone that responds to Mycobacterium tuberculosis and to cartilage proteoglycans. Proc Natl Acad Sci U S A 1985;82:511720

5 Panayi GS. The immunopathogenesis of rheumatoid arthritis. Br J Rheumatol 1993;32 suppl 1:4-14.

6 Firestein GS, Zvaifler NJ. How important are T cells in chronic rheumatoid synovitis? Arthritis Rheum 1990;33: 768-73.

7 Firestein GS. Invasive fibroblast-like synoviocytes in rheumatoid arthritis. Passive responders or transformed aggressors? Arthritis Rheum 1996;39:1781-90.

8 Thomas R, Lipsky PE. Presentation of self peptides by dendritic cells: possible implications for the pathogenesis of rheumatoid arthritis. Arthritis Rheum 1996;39:183-90.

9 Kaye BR, Kaye RL, Bobrove A. Rheumatoid nodules. Review of the spectrum of associated conditions and proposal of a new classification, with a report of four seronproposal of a new classification, with a report

10 Miyasaka N, Sato K, Yamamoto K, Goto M, Nishioka K. Immunological and immunohistochemical analysis of rheumatoid nodules. Ann Rheum Dis 1989;48:220-6.

11 Ziff M. The rheumatoid nodule. Arthritis Rheum 1990;33: 761-7.

12 De Keyser F, Verbruggen G, Veys EM, Cuvelier C, Malfait $\mathrm{AM}$, Benoit $\mathrm{D}$, et al. $\mathrm{T}$ cell receptor $\mathrm{V}$ beta usage in rheumatoid nodules: marked oligoclonality among IL-2 expanded lymphocytes. Clin Immunol Immunopathol 1993; 68:29-34.

13 De Keyser F, Elewaut D, Overmeer-Graus JPM, Van Den Broek P., Rijnders AWM, Veys EM. Dominant T cell receptor rearrangements in IL-2 expanded lymphocytes from rheumatoid nodules suggest an antigen-driven $T$ cell activation in situ. J Rheumatol 1997;24:1685-89.

14 Mojcik CF, Shevach EM. Adhesion molecules: a rheumatologic perspective. Arthritis Rheum 1997;40:991-1004.

15 Arnett FC, Edworthy SM, Bloch DA, McShane DJ, Fries JF, Cooper NS, et al. The American Rheumatism Association 1987 revised criteria for the classification of rheumatoid arthritis. Arthritis Rheum 1988;31:315-24.

16 Lazarovits AI, Karsh J. Differential expression in rheumatoid synovium and synovial fluid of alpha 4 beta 7 integrin. A novel receptor for fibronectin and vascular cell adhesion molecule-1. J Immunol 1993;151:6482-9.

17 Lazarovits AI, Moscicki RA, Kurnick JT, Camerini D, Bhan AK, Baird LG, et al. Lymphocyte activation antigens. I. A monoclonal antibody, anti-Act I, defines a new late lymphocyte activation antigen. J Immunol 1984;133:185762 .

18 Dustin ML, Rothlein R, Bhan AK, Dinarello CA, Springer TA. Induction by IL 1 and interferon-gamma: tissue distribution, biochemistry, and function of a natural adherence molecule (ICAM-1). J Immunol 1986;137:245-54.

19 Bevilacqua MP, Pober JS, Mendrick DL, Cotran RS, Gimbrone MA, Jr. Identification of an inducible endothelialleukocyte adhesion molecule. Proc Natl Acad Sci USA 1987;84:9238-42.

20 Bevilacqua MP. Endothelial-leukocyte adhesion molecules. Annu Rev Immunol 1993;11:767-804.

21 Osborn L, Hession C, Tizard R, Vassallo C, Luhowskyj S, Chi Rosso G, et al. Direct expression cloning of vascular cell adhesion molecule 1 , a cytokine-induced endothelial protein that binds to lymphocytes. Cell 1989;59:1203-11.

22 Palmer DG, Hogg N, Highton J, Hessian PA, Denholm I. Macrophage migration and maturation within rheumatoid nodules. Arthritis Rheum 1987;30:728-36.

23 Athanasou NA, Quinn J, Woods CG, Mcgee JO. Immunohistology of rheumatoid nodules and rheumatoid synovium. Ann Rheum Dis 1988;47:398-403.

24 Edwards JC, Wilkinson LS, Pitsillides AA. Palisading cells of rheumatoid nodules: comparison with synovial intimal cells. Ann Rheum Dis 1993;52:801-5.

25 Del Prete G, De Carli M, Almerigogna F, Daniel CK, D'Elios MM, Zancuoghi G, et al. Preferential expression of CD30 by human CD4+ T cells producing Th2-type cytokines. FASEB J 1995;9:81-6.

26 Ellis TM, Simms PE, Slivnick DJ, Jack HM, Fisher RI. $\mathrm{CD} 30$ is a signal-transducing molecule that defines a sub-
set of human activated CD $45 \mathrm{RO}+\mathrm{T}$ cells. J Immunol 1993;151:2380-9.

27 Veys EM, De Keyser F. Rheumatoid nodules: differential diagnosis and immunohistological findings. Ann Rheum Dis 1993;52:625-6.

28 Kerstens PJ, Boerbooms AM, Jeurissen ME, Fast JH, Assmann KJ, van De Putte LB. Accelerated nodulosis during low dose methotrexate therapy for rheumatoid arthritis. An analysis of ten cases. J Rheumatol 1992;19:867-71. 